\title{
ブータン王国パロ県の農村集落チュバ及びアツォにおける 伝統住居の屋内平面空間構成に関する研究
}

\author{
各部屋の現地ゾンカ語呼称と用途に着目して
}

\section{A STUDY ON THE SPATIAL ORGANIZATION OF FLOOR PLANS OF TRADITIONAL BHUTANESE HOUSES IN TWO VILLAGES CHUBA AND ATSUO, PARO DZONGKHAG, KINGDOM OF BHUTAN}

Focusing on the name of each room/space in local Dzongkha language and room use

\author{
磯野 綾*, 吉村晶子**, 金子将大*** \\ Aya ISONO, Akiko YOSHIMURA and Shota KANEKO
}

\begin{abstract}
This study aims to understand spatial organizations inside traditional Bhutanese houses through an empirical survey in Paro, Western Bhutan, on the uses of rooms and their names in Dzongkha. The results indicate that the main floor includes an intermediate space (Bako in Dzongkha), a living room (Youkha), and an alter room (Choshom) with an inner altar room (Tshamko). The window side in the Youkha is the primary place for the view and breeze, and traditionally had precedence. Some local Dzongkha room names differ from English names in that they express the spatial placement of rooms rather than their functions.
\end{abstract}

Keywords : Bhutan, Traditional Houses, Floor Plan Layout, Room Name, Field survey, Spatial Recognition ブータン，伝統住居，間取り，部屋名，実踏調査，空間認識

\section{1. 研究の背景と目的}

\section{1-1. 研究の背景と目的}

ブータン王国では生業と生活、仏教文化、生活文化に支えられた 文化的景観を保持する伝統的農村集落が多く残されている。

しかし、そのブータンにおいても近年ではグローバル化とともに いわゆる近代化が押し寄せてきており、都市化と集中注1)、車やテレ ビなどの近代的利便機器の急速な浸透注2)など、変化に直面している。 一方、住宅建築では都市部においては木、土、石などの従来の建材 を用いた古い伝統住居のほか、コンクリートを使用した現代建築が 建てられるようになっている。また急速な都市化の為に、団地化し た集合住宅も登場し、急傾斜地に建つ違法建築注 3) も散見される状 況となっている。さらに、近年の土地所有制度の変更で最小敷地の 制限が緩和され土地の細分化が可能となり、利活用が難しい微小敷 地が増加するなどの問題も発生している。このため、材料ばかりで なく、空間の持つ意味や質も変化してきている可能性がある。機能 重視で周辺の文脈より切り取られ断片化した空間の発生や、仏教的 倫理観のもとで環境内存在 ${ }^{1)}$ として生きてきたブータン人であれば 本来望まないであろう変化が今後もたらされるなどの懸念がある注 ${ }^{4}$ 。 これらの社会的背景のもと、本研究は、ブータン伝統住居の屋内
空間に対する居住者の空間認識や各室の意味を考察するための基礎 資料とするため、同国西部のパロ県内にあるチュバ集落及びアツォ 集落に今も残る伝統住居を対象に、その間取り及び屋内空間構成を 実測・実踏調查により記録として残し、さらにヒアリング調查によ り (1)各部屋の使われ方の具体的事例(2)屋内空間の基本構成と各室の 現地ゾンカ語呼称を明らかにすることを目的とする。

\section{1-2. 既往研究からみた本研究の意義}

住居の間取りや屋内空間構成に関する調査研究は本国内外を問的 ず数多くなされており 2)3445)、材料の使用方法や内部空間の構成は歴 史や文化伝搬の影響を強く受けることや、地方文化や地方経済と結 びつき「地域的な型」を形成することなど、敷地環境の文脈を示す 部分であることが示唆されている。しかしながら、ブータンにおけ る伝統住居に関する調查研究はまだまだ少ない。ブータンの建築に 関する研究としては、ゾン Dzong（城塞と寺院と行政府の役割をも つ）やラカン Lhakhang（寺院）を対象としたものが主である6)7)。 ブータン伝統住居がもつ風土に根ざしたヴァナキュラーな建築と しての価值については古市ら ${ }^{8}$ が指摘しているところである。ブー タン伝統住居で展開されてきた持続可能な生き方や環境と共生する

\footnotetext{
* 習志野市都市整備部 博士 (工学)

** 千葉工業大学 准教授・博士 (工学)

*** 千葉工業大学大学院 学士(工学) 
知恵をよりよく理解するにはブータン人自身がどのように屋内空間 を認識しているかについて知見を得ることがその一助となると思わ れる。その際、ブータンとは異なる文化圈・語族の言語である英語 で室名を把握するのではなく、現地語における部屋名呼称を把握す ることができれば、かようなブータン人の屋内空間認識を理解する 契機となると考えられる。先行研究には建築実測調查、デザイン・ サーベイの成果は存在し、詳細な図面記録がとられているが、それ ら図面では室名は日本語又は英語表記で記載されるのみである。

例えば、岸本らはパロの古民家及び農家建築について、家系図、 立地場所の特徵、建築物の構成、住民の生活、建物の平面図及び構 成アイソメを調查・記録している910)。また、青木は伝統的建造物の 保存修復手法や構造補強の方法確立のため、版築の伝統的な工法に ついて地盤の常時微動測定調査の実施や版築の築造方法についての 詳細な記録を残している1112)。しかしながら、これらの先行研究で は伝統住居の屋内空間の基本構成や各部屋の使われ方にまで言及し ているものはない。

本研究は以上の着眼から、調查対象地における現地語での部屋名 呼称の調查を部屋の使われ方の聞き取り記録とともに実施するもの である。

\section{1-3. 伝統住居の概要}

対象となるパロ県における伝統住居の特徴等について、本節では 先行研究13114)に基づき概要を整理する。

パロ県の伝統住居は 3 層又は 4 層建ての版築と木造の混構造から なり、各階によって空間構成は異なる。各階は取り外し可能注 ${ }^{5)}$ な 急勾配（勾配：60 度以上）のはしご状の階段で繋がっている。

建材は地域に豊富にある土、石、木などである。建物基礎は石を 土モルタルで積み、その上に、備熱性能が高く、冬の寒さや夏の暑 さに対して比較的温度変化が少なく室内空間を快適に保つことがで きる版築の壁が築造される。二層目以上の構造は建物の中央部の壁 が版築で、その周りの部屋の壁が木製である。版築部は厚さが $80 \mathrm{~cm}$ になるものもあり、極めて高い断熱性能を持つほか、耐久性もあり、 100 年以上の長期にわたって保持できる特徵がある。

これらの壁面には用途や設置位置に応じ開口部：Rayab（空）、 Mago（主たる出入り口）、Geykar（換気空）が設置され、特に上層 の Rayab（空）には男性器又は女性器を表す 2 種類の空枠が存在し ており、宗教的願いが込められた模様で彩色された鮮やかな壁画や 舟肘木と共に特徴的な外観を形成している（図 2)。

また、屋根の小屋組みは躯体とは別構造で、陸屋根の上に梁（重 㱛梁含む）を輪薙込みで組んだ小屋組みを束で支えて載せてある。

\section{1-4. 研究対象}

(1) 研究対象地及び研究対象となる伝統住居

本研究はブータン政府公共事業省との共同調查であり、調查対象 集落は規模としてまとまった戸数を持ち、また伝統的集落として保 存状態のよい集落として同省から提案された候補の中から選定した。

調查対象集落はブータン王国西部、ブータン第 2 の都市・パロの あるパロ県内のチュバ（Chuba）及びアツォ（Atsuo）の 2 集落とし た (図 1)。両集落はパロの市街地から約 $7 \mathrm{~km}$ 北に位置する。パロ 市街には西からパロ・チュ注6)、北からダ・チュが流れこみ、2つの

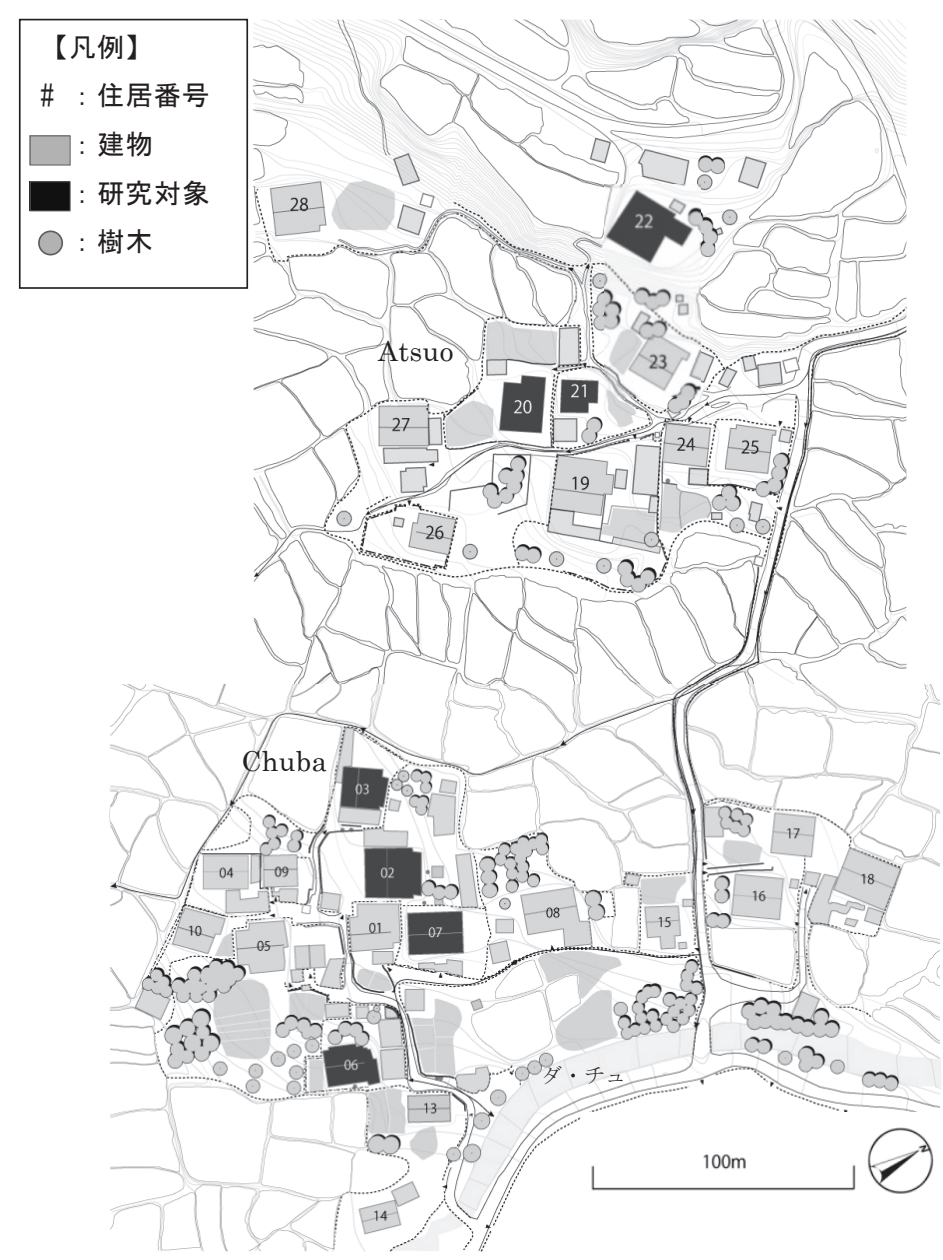

図 1 研究対象地

表 1 研究対象住居の概要

\begin{tabular}{|c|c|c|c|c|c|c|c|}
\hline \multirow{2}{*}{$\begin{array}{l}\text { 集 } \\
\text { 落 }\end{array}$} & \multirow{2}{*}{$\begin{array}{l}\text { 住居 } \\
\text { 番号 }\end{array}$} & \multicolumn{4}{|c|}{ 階数 } & \multirow{2}{*}{$\begin{array}{c}\text { 建物正面の } \\
\text { 方位 }\end{array}$} & \multirow{2}{*}{$\begin{array}{l}\text { 主要な出入口 } \\
\text { の方位 }\end{array}$} \\
\hline & & 1 層 & 2 層 & 3 層 & 4 層 & & \\
\hline \multirow{4}{*}{$\begin{array}{l}\text { チ } \\
\text { バ }\end{array}$} & No.2 & 0 & 0 & (2) & 0 & 南西 & 南西 \\
\hline & No.3 & 0 & (2) & 0 & & 南西 & 南西 \\
\hline & No.6 & 0 & (2) & 0 & & 東 & 東 \\
\hline & No.7 & 0 & 0 & (2) & $\mathrm{O}$ & 南西 & 南西 \\
\hline \multirow{3}{*}{$\begin{array}{l}\text { 尽 } \\
\text { 勿 }\end{array}$} & No.20 & 0 & (2) & $\mathrm{O}$ & & 南西 & 南西 \\
\hline & No.21 & 0 & (2) & 0 & & 北西 & 北東 \\
\hline & No.22 & 0 & (2) & 0 & & 南東 & 南東 \\
\hline
\end{tabular}

【凡例】○該当する層が有り、@主たる居住空間の層

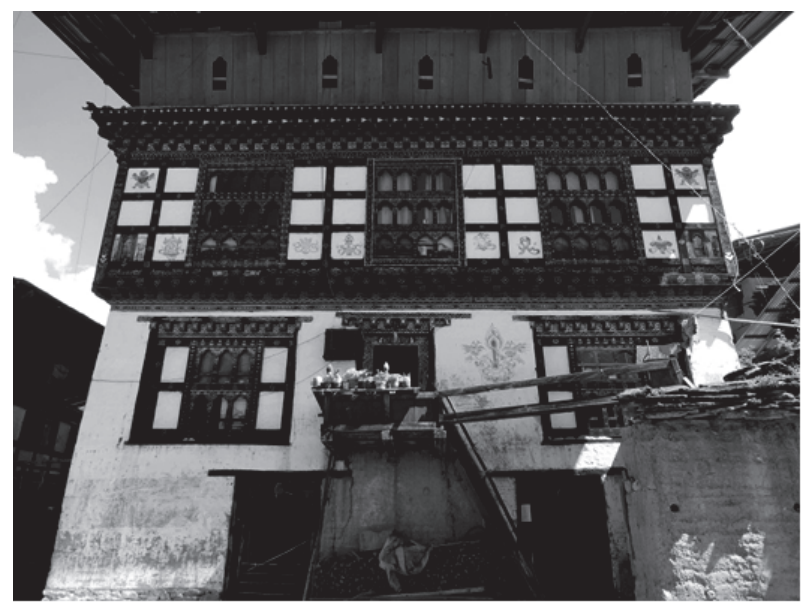

図 2 チュバ集落の伝統住居（No. 2）の外観 
川はパロ市街の西で合流する。チュバ、アツォの 2 集落は、パロか ら見て北側、ダ・チュの約 $7 \mathrm{~km}$ 上流の右岸にある。

この地域の年間降水量は $1,500 \mathrm{~mm}$ 程、モンスーン気候地帯である。 集落の居住地を囲むように耕作地があり、稲作などが行われている。 また、集落では牛などの家畜を飼育しており、里山から落ち葉を人 力で住居敷地内の小屋に運んで保管し、これと牛糞で堆肥をつくり 耕作に用いている。

両集落は標高 $2,350 \mathrm{~m}$ 程度に位置し、両側には標高 $3,700 \mathrm{~m}$ 程度の 山がそれぞれある。集落に近い山裾から標高差 $100 \mathrm{~m}$ 程度の中腹に かけては集落の里山（Sokshing）となっている。チュバは川沿いに 位置し、ブータンの集落としては少ない、かなり平坦といえる地形 へ立地している。一方、アツオはチュバの北西約 $100 \mathrm{~m}$ にあり、里 山からは約 $200 \mathrm{~m}$ 東に位置し、山裾の傾斜がやや残る地形に立地し ている。筆者らの 2013 年度調査 ${ }^{15)}$ の測量成果によると、集落内の主 要動線の傾斜はチュバで $2.2 \%$ 、アツォで $4.4 \%$ でった ${ }^{16)}$

両集落の住居はいずれも前節で整理した特徴を持ち現在も居住の 用に供している。その多くが築 100 年前後またはそれ以上の住居で あり主7)、本研究ではこれらをチュバ及びアツォ集落における伝統住 居と定義し、この内チュバ集落 4 住居、アツオ集落 3 住居を対象と した（図 1、表 1、図 2)。

\section{2. 調査期間及び調査方法}

以下の期間で 2 回の現地調查を行い、空間の基本構成パターン及 び使われ方の類型を明らかにし、チュバ及びアツォ集落の伝統住居 の特徵を整理した。

（1） 2013 年 9 月 17〜20日

チュバ集落において伝統住居 8 住居の外観及び内部の実測、伝統 住居敷地周辺の集落内の地形の測量などを実施する調查に参加し、 各伝統住居の家族構成、生業、屋内各室の現地ゾンカ語呼称及び使 われ方についてのヒアリング調査を実施した注8)。

（2） 2014 年 9 月 $16 \sim 19$ 日

チュバ及びアツォの両集落の対象となる各伝統住居の屋内空間の 各室の現地ゾンカ語呼称及び使われ方についてヒアリング調查を行 なった。この内チュバ集落は前年に調查した 8 住居のうち 4 住居を 対象とした注9)。

ヒアリング調查においては、2013 年調查では現地でのスケッチを、 2014 年調查では前年の実測成果により予め作成した間取り図を調 查票とし、住民に確認した各部屋の呼称や使われ方を記入した。な お、ブータン国内では 20 程度の方言 ${ }^{17718)}$ が使用されており、地方に よって部屋名呼称が異なると思われる。今回の調查対象地であるパ ロ県はゾンカ語が用いられる地域に含まれることから、本研究では 対象住居における部屋名呼称の現地ゾンカ語の発音をラテン文字表 記で記録した。

部屋名呼称の記録においては、住民より聴き取った現地ゾンカ語 の部屋名呼称の発音を、本調查に同行した 2 名の英語-ゾンカ語通訳 者にラテン文字表記でノートに記入してもらい記録した注 ${ }^{10)}$ 。なお、 英語-ゾンカ語通訳者として、2013 年調査ではブータン国立博物館 学芸員、2014 年調查ではこれに加えブータン政府公共事業省職員で 建築・都市計画を専門とする担当者の協力を得た。

\section{3. 伝統住居の平面空間構成の特徵}

\section{3-1. 伝統住居の基本構成}

集落の中でも住居の平面空間構成の特徵及び近代化に伴う変化等 の詳しいヒアリング調査が特に行えた伝統住居 No.6 を例に以下に 伝統住居の平面空間構成の特徵を階層ごとに述べる。

No.6 の家族構成は当主夫婦、当主の兄、当主の息子夫婦、孫娘で あり、現在は 3 世代 5 人が住んでいる（図 3 ）。母系家族の社会構造 をもつブータンにおいて、パロ地方では女性が家を継ぐ場合も多い が、男性が家を継ぐケースもあり19)、No.6 では現当主は男性である。

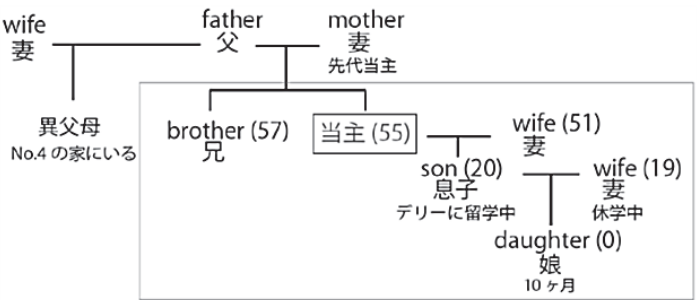

図 3 No. 6 の住民

（1） 1 層目：非居住空間（図 4、図 5)

本層は中心となる牛部屋と、それに付随する階段のある空間と飼 料を作る部屋から成る。飼料が家畜に食べられないよう、旧牛部屋 と飼料を作る部屋は階段のある空間を挟んで別空間となっている。 近年、衛生上の問題から政府によって動物と同棟に住むことが禁止 され、別棟に移すよう指導されるようになったことから、敷地内に 牛舎が建設され、牛部屋や飼料を作る部屋は主に現在は倉庫として 使用されるようになった。この内、現在も使用されている PHUNG （食品の貯蔵場所）には部屋名呼称があったが、それ以外の部屋は 特定の部屋名呼称はない。

（2）２層目：主たる居住空間（図 4、図 5）

本層が主たる居住空間であり、版築部にある中心部空間と、側方 に張り出した縁辺部空間から成る。

中心部空間は、BAKONA と呼ばれる空間（カマドがあり、炊事 場にあたる THAPTSHONA/TAPTSON でも呼ばれる。後述参照)、 YOUKHA/YUKI と呼ばれる部屋 (居間・客間・寝室にあたる部屋)、 CHOSHOM と呼ばれる仏間（外陣と内陣の 2 室からなり、内陣は TSHAMKO と呼ばれる）がある居住空間の中心である。No.6 では これら各室が田の字型をなす平面構成となっている（図 4）。

BAKONA は通訳者の英語訳では corridor と訳され、ゾンカ語で $「 \mathrm{BA} 」 は 「($ 何かと何か) の間、中間」という意味をもつことから、 上下層を繋ぐ階段室とYOUKHA とのあいだにある中間の間として 廊下に近い認識でとらえている空間のようである。この BAKONA にはカマドがあり、現在は流しも設置され、主に炊事を行う部屋と なっている。そのためNo.6 の住民は通訳を介しこの部屋を英語で kitchen、ゾンカ語で THAPTSHONA/ TAPTSON と説明する注 11)。 炊事場つまり台所にあたる部屋であるが、逐語的にはカマド (THAP) のある場所 $(\mathrm{TSHO})$ を意味する呼称である (NA は屋内を意味する)。 保温性のある版築部にあって火を使用することから暖かく、冬場は この部屋に家族が集まるなどよく使われる部屋となっている。また、 農繁期などに親戚らが大勢手伝いに来て泊まる際にはYOUKHA に 収容しきれない者はBAKONA で寝るとのことである。

TAPTSONの東側の部屋はYOUKHA/YUKI と呼ばれている注 ${ }^{12)}$ 
普段家族が座る部屋であると同時に、客をもてな寸など多くの活動 がおこなわれる部屋である。この空辺にはテーブルと椅子が設置さ れていたが、本来は床に座るスタイルである（図 6、後述参照）。

YOUKHA/YUKI の南側には CHOSHOM（仏間）に繋がる装飾 が施された扉がある。CHOSHOM は外陣と内陣の 2 室からなる。 中でも内陣を特に「TSHAMKO/TSAMKO」と呼ぶ住居もあり、No.6 でも内陣を TSAMKO と呼んでいた（以下、TSHAMKO とする）。 YOUKHA/YUKI から CHOSHOM の外陣側に入って初めて TSHAMKO（内陣）を見ることが可能である。このように TSHAMKO は中心部空間の各室のなかでも最も奥に位置し、仏壇 が設けられ、家の中で精神的に最も重要な聖なる空間となっている。 No.6 の CHOSHOM の外陣は YOUKHA/YUKI と同様、川に面する 方向に空があり、室内は明るい。

一方の縁辺部空間は、No.6 の家の場合は中心部空間の北側及び西 側の 2 か所に YOUCHU/YUCHU 注 ${ }^{13)}$ (側方への張り出し部) があ る。北側 YOUCHU には上下層に繫がる階段がある。廊下はなく、 部屋を通り次の部屋へと行く間取りであるため、北側 YOUCHUに ある GOBANA（主要な出入口）から階段室を経由し中心部空間に 繋がる。また、西側 YOUCHU が、JABYOUG (裏の空間)である。 ここには現在 2 部屋あり PHUNG（食品の貯蔵場所）として使われ ている。

（3） 3 層目：収穫物等を乾燥・保存する空間（図 4、図 5)

最上階である本層の中心は、収穫した穀物や唐辛子、干し草等を 乾燥し保管する YOUTAKHA/YOTO 注 ${ }^{14)}$ （最上層、屋根裏）であ る。この YOTO に YOUCHU が付随する空間構成となっている。 中でも YOTO の西側 YOUCHU には 2 部屋あり、一方が当主の息 子夫婦の寝室として現在使われている。昔は別用途であったが、息 子夫婦の結婚後家族全員が YUKI で寝るには手狭となったことか ら YOUCHU が息子夫婦の寝室となり主 ${ }^{15)}$ 、使われ方が変化した。

\section{3-2. 各部屋の使われ方の特徴}

住居 No.6 の調査を通し、伝統住居の使われ方や空間構成におけ る伝統的な部分と近代化に伴う変化の一例を確認寸ることができた。

伝統的な部分としては、主たる居住空間の部屋の配置が挙げられ、 なかでも BAKONA は他言語でとらえにくいブータン伝統住居に特 徵的な空間として特筆される。また、YOUKHA の生活における中 心性と多様な活動に対応する汎用性、またその奥にあって精神的な 中心をなす仏間 CHOSHOM・TSHAMKO の重要性も挙げられる。

BAKONA については、YOUKHA に次ぐ面積をもつ部屋であり 形状も四角い部屋であるにも関わらず、前述のとおり階段室と YOUKHA をつなぐ中間 (「BA」) の間として廊下に近い認識でとら
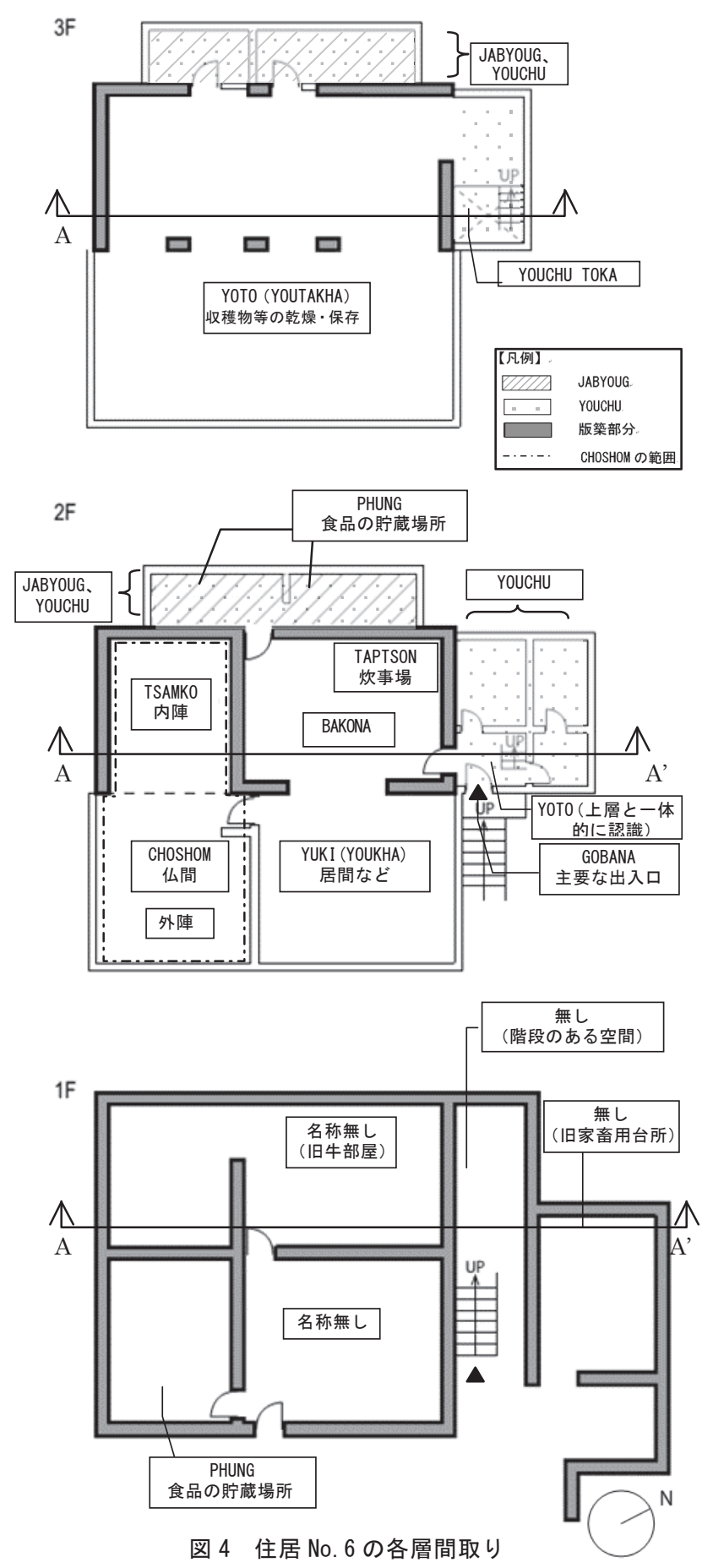

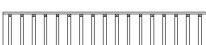

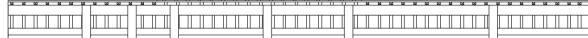

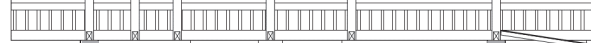

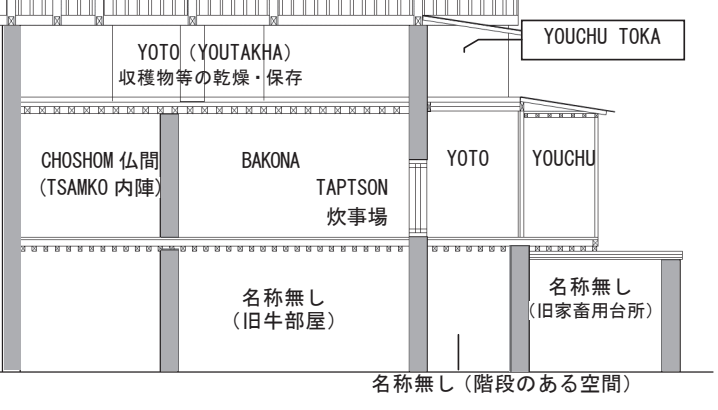

図 5 住居 No. 6 A-A' 断面図

【凡例】

版築部分 
えられており、部屋としての認識は希薄なようである注 16)。

階段室つまり上下層につながる BAKONA の中に、カマドのある 場所THAPSHONA が設けられているのは換気の面で理にかなった 伝統的構成であり、煙による殺虫燻蒸効果等もあったと考えられる。

次に、CHOSHOM 及び TSHAMKO の重要性はその床面積と配 置から確認できる。2 層目（主な居住空間）の床面積に対する CHOSHOM 及びTSHAMKO の床面積比率は約 $1 / 3$ で最も広い部屋 となっており、TSHAMKO は CHOSHOM（外陣側）以外からは見 えない配置となっている。このことは、伝統住居における TSHAMKO の重要度の高さと神聖性を示唆しているものと考えら れる。

一方、近代化に伴う変化の現われの一つ目はYOUKHA (YUKI) の空辺に椅子とテーブルが設置されていたことである。前述の通り、 本来は床に座るスタイルであり、古来の伝統においては、YOUKHA
にはZAPEN と呼ばれる男性当主が座る席が決められていた。そこ にはZHUDEN と呼ばれる当主専用の座布団が設えられ、当主が座 った。その男性当主の席が設えられるのは、YOUKHA の中でも空 に最も近い場所であった。来客や家族等は、当主を取り囲むように して輪になって座り、空に近いほうから上座となる。子供などは下 座、つまり空から最も遠い席となる（図 6)。

加えて、本来 YOUKHA (YUKI) は、時に応じて使われ方が変 わる部屋である。例えば、常時には家族団欒の場所として、就寝時 には寝室として、来客時には応接部屋として、葬礼の際には一連の 尔いに伴う行事に関連して使われる。その中で、人が集まる際には 空辺に座る当主を必ず一重の輪で囲む空間作法があった。つまり、 従来は人数に応じて輪の大きさを変えることで、少人数から大人数 の集まりまで臨機応変に対応できる部屋であった。しかしながら、 椅子やテーブルを設置することで、現在も空辺が「座る」という行
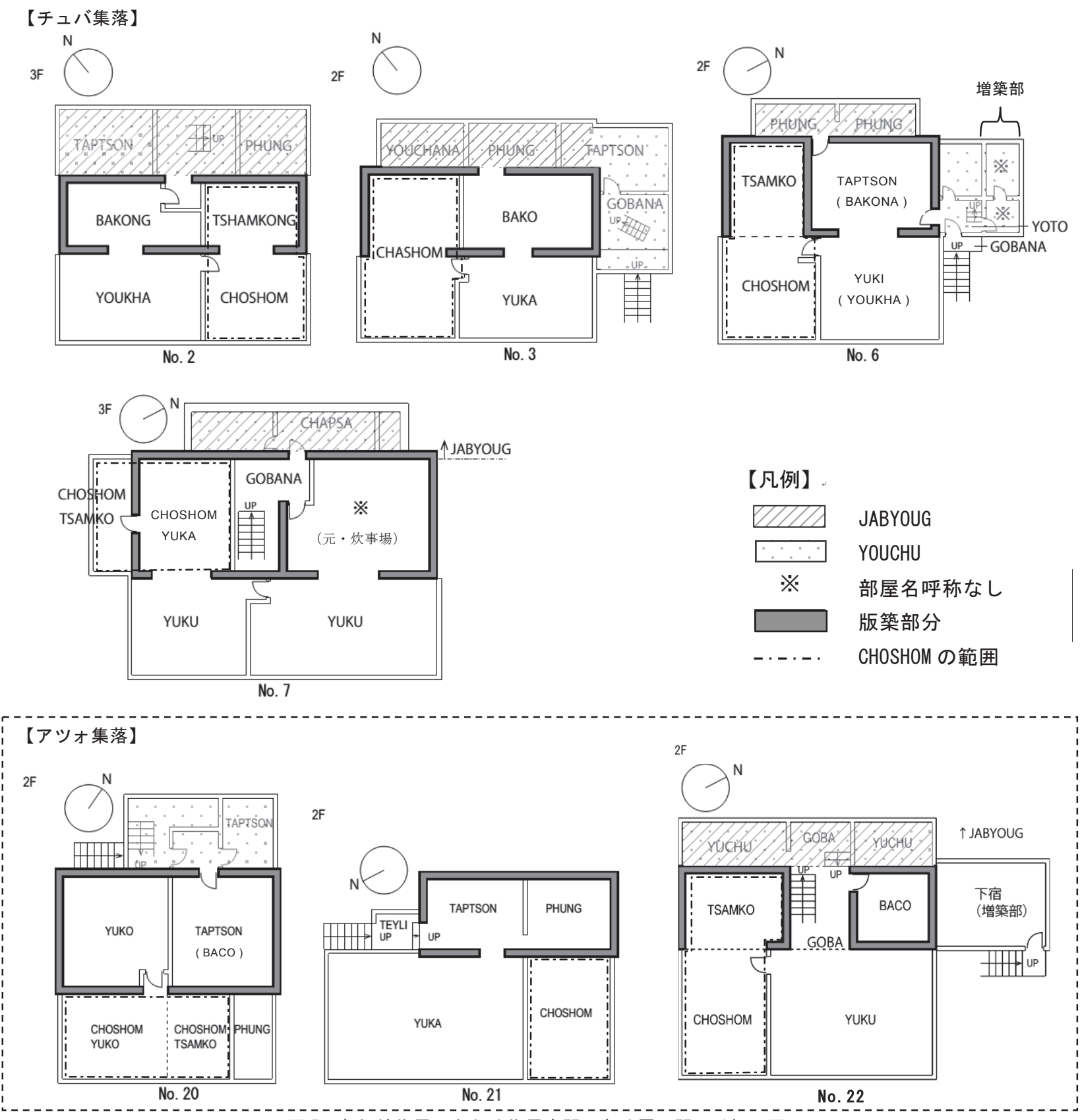

図 7 各伝統住居の主たる住居空間である層の間取り概要図 
為を行う場所であることという伝統的な空間認識はあるものの、 No.6 の場合は YUKI の約 13\%にあたる空間が椅子等により占めら れ「限られた人数が座る空間」という使われた方に変化していた。

二つ目は、YOUCHU が息子夫婦の寝室として使われるようにな った点である。前述のとおり、従来の伝統住居ではYOUKHA(YUKI) が寝室の役割を内包しており、西欧の「BED ROOM」に相当する 専用の部屋はなかった。それが近代化に伴い他文化圈の情報や習慣 がブータン西部にも伝播したことで、「息子夫婦の寝室」という個人 で機能別の部屋を有する「部屋の個室化」が見られるようになった。 また、No.6ではなかったが類似例としてNo.4では僧侣が座し祭祀
を行うCHOSHOM 外陣側の一角を子供部屋として使用していた。 YOUKHA の隣室であり、中心空間の一角を構成している部屋であ ることから、個室化したYOUCHU と比べると密室度は低いものの、 使われ方の変化の一例といえる。なお、CHOSHOM には、主要な 宗教儀式 Puja の際に僧侶が泊まることもあり、主人と男性の客人 は CHOSHOM で寝てもよいが女性は不可という伝統的な空間作法 があったが、現在ではこれは崩れつつある。

これらの変化は、縁辺部空間にあり、増築による設置も可能な YOUCHU が最も個室化しや寸い空間であることを、また床面積の 大きい CHOSHOM（外陣側）が中心部空間の中では個室化や本来

表 2 各伝統住居の調査時における各部屋の使われ方及び存在する階層の一覧

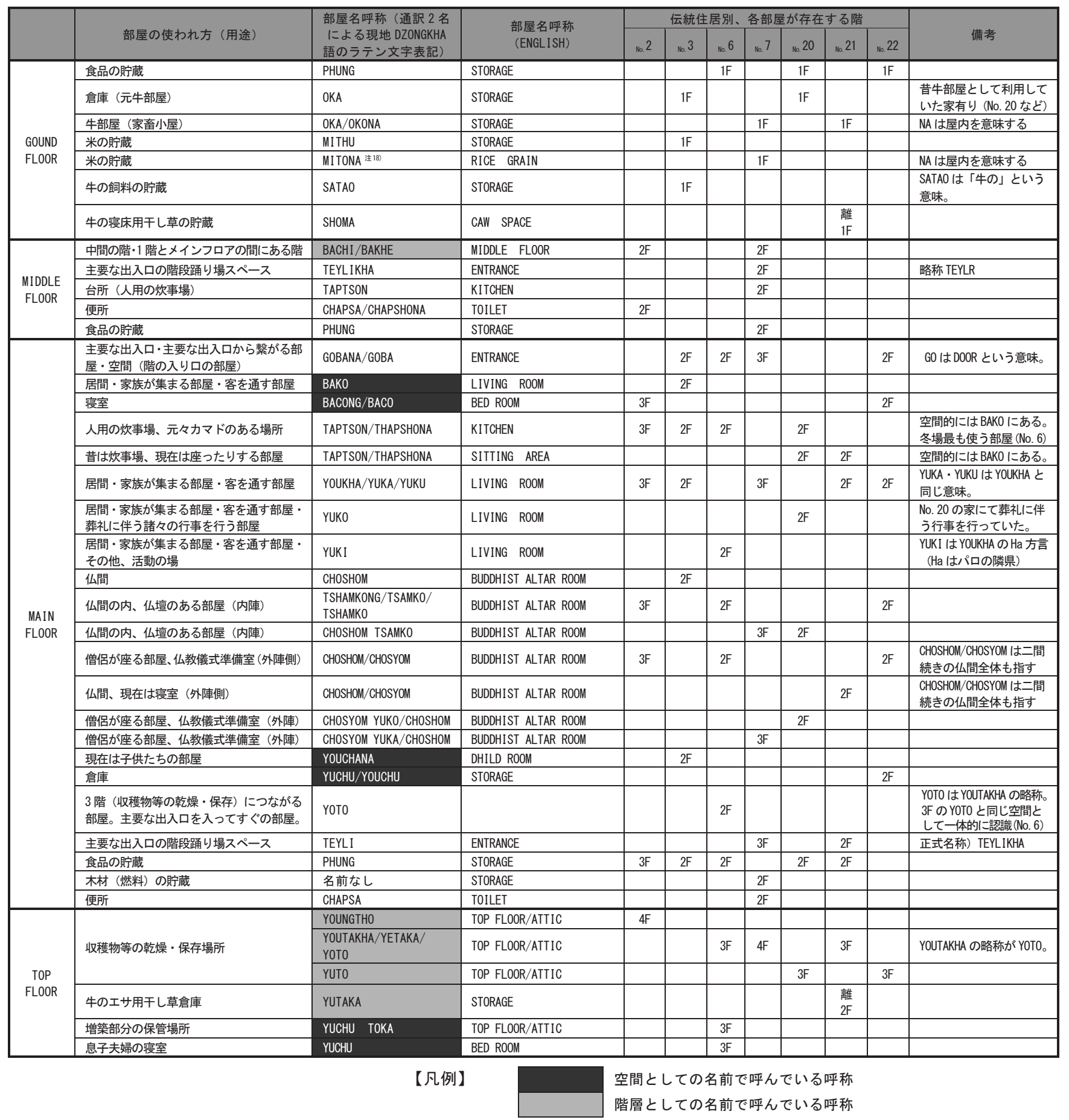


の使われ方以外にも使用されやすい空間であること示唆している。 以上のことから、近代化に伴う空間作法の変化や部屋の個室化が 進行している状況の一端を把握したといえるのではないかと考える。

\section{4. 屋内空間の構成とゾンカ語の部屋名呼称の特徵}

本章ではまず屋内空間の概要を横断的に整理した上で、現地ゾン 力語の部屋名呼称の特徵を整理する。

\section{4-1. 屋内空間の特徵}

第 3 章でみた No.6の例の通り、伝統住居は各階によって空間構成 が異なり、1 層目は家畜部屋又は倉庫や貯蔵などに用いられる非居 住空間、その上層は主たる居住空間、最上層は収穫物等の乾燥 - 保 存場所であり、これは調査した全伝統住居に共通している。また平 面構成も、1 層目は家畜部屋を、居住空間は BAKO/BAKONA、 YOUKHA、CHOSHOM、TSHAMKO からなる田の字の構成を、最 上層YOUTAKHA は乾燥・保存場所とされている点も共通している。 各層における共通点は次の通りである。

1 層目は家畜部屋又は倉庫・貯蔵場所などに用いられる。家畜部 屋を別棟に移した No.6、No.7 及びNo.21 以外の伝統住居では 1 層目 は農具や穀物の倉庫として利用されている。元々居住空間ではない ためか、この層の部屋には空がなく、日中であっても室内は暗い。 壁は版築で、各部屋は扉でつながっている。

2 層目は、建物内部に 1 層目から 2 層目一繋がる階段がなく、外 部に設けられた階段を使い、2 層目の入り口から内部一入るように なっている。ただし、4 層建ての場合と 3 層建ての場合では 2 層目 の空間構成と使われ方が異なる。

4 層建て 2 住居（No.2、No.7）のうち、No.2の 2 層目（BACHI と 呼ばれる層。後述参照) には便所と特定の名前のない室が、また No.7 は食品の貯蔵場所、炊事場が設けられている。

3 層建ての場合は 2 層目が主たる居住空間であり、4層建ての場合 は 3 層目がこれに該当する。主たる居住空間の層には英語の「MAIN FLOOR」に相当するような特定の層の名前が存在しない。

中心部空間の構成は共通しているが、住戸毎に間取りは異なり、 調查対象の各伝統住居におけるこの層の間取りは図 7 の通りである。 この中心部空間うち YOUKHA と CHOSHOM は先行研究では日照 通風の良い東南隅に配置されることが多いとされるが20)、本調查で はその法則性は見いだせなかった注 ${ }^{17}$ 。YOUKHA は家族が集まる部 屋、共同で農作業にあたる結の仲間や客を通寸部屋などとして住居 の中で最も多様な活動が行われており、夜も家族がここで集まって 寝るなど家族が集う中心的な空間となっている。調查中にはNo.20 の伝統住居で葬礼後の一連の赤いに伴う行事に関連して YOUKHA （YUKO）が使われる例もみられた。二間続きとなっている仏間 CHOSHOM のうち、外陣は僧侶が座し祭祀を行うほか、祭祀の準 備や儀式に用いる道具類を保管する用途に用いられる。その奥には TSHAMKON（内陣）が設けられ、部屋全体が仏を祀る座となって いる。この二間続きの構成は全ての住戸に共通した配置であった。

一方、BAKO/BAKONA の空間の使われ方は住居によって異なる。 No. 2 及びNo. 22 は家族が寝る場所として、No.3、No.20はYOUKHA に次ぐ機能を持つ部屋として、No.6 は THAPTSON として使用し ている。No.7 は元々、食事を作る場として使用していたが、現在は 固定の機能や部屋名呼称を付与されていない注 19)。
また、縁辺部空間の呼び名や使われ方は住居によって異なる。 No.2 及び No.20 では TAPTSON、PHUNG、No.3 は TAPTSON、 PHUNG、子供たちの部屋として使われる YOUCHANA、No.6 は PHUNG、No.7 は木材貯蔵場所である部屋名呼称のない空間、 PHUNG、No.21 ではPHUNG、家族が座る空間、No.6 は倉庫とし て使用されている YOUCHU として使われている。全ての住居で、 縁辺部空間は何かを貯蔵する場所として使っている。

また、縁辺部空間には No.2、No.3、No.20 でTAPTSON が、No.7 では CHAPSA（便所）といった水を使用する部屋が配置されてい た。TAPTSON は中心部空間に設けられる場合も縁辺部空間に設け られる場合もある。なお、炊事道具に関し、No.2、No.20では木造 の床の上の土間にカマドを設置した昔ながらの方法で炊事をしてい る一方、No.3、No.6では現代的な流しやコンロなどに変わっていた。

最上層は壁がなく、直射日光の当たらない半外部空間で風通しが 良いことから、全ての住居で干し草、唐辛子、山椒、干し肉などの 乾燥・保存場所に用いられている。

以上、部屋名呼称と空間の使われ方に着目した調查により、各層 の中心となる空間の使われ方は全ての伝統住居に共通していること、 中間階 $(\mathrm{BACHI}) 、$ 中間の間 $(\mathrm{BAKO}) 、$ 縁辺部空間 (YOUCHU) の使われ方は各伝統住居で差異があることを確認できた。

\section{4-2. ゾンカ語の部屋名呼称}

ブータンの部屋名呼称は、英語圈と同じように機能によって特定 の部屋名呼称で呼ばれる場合と、空間としての名前で呼ばれる場合 とがある（表 2)。

（1）機能に基づく部屋名呼称

特定の機能を有する部屋に対して名前が付与されていたものは、 GOBA (主要な出入口)、MITHU（米の貯蔵）、OKA (牛部屋)、 SATAO (牛の飼料部屋)、SHOMA (牛の寝床用干し草倉庫)、及び THAPSHONA/TAPTSON（炊事場）である。

仏間にあたる部屋は、No.3、No.21では内陣外陣の区別なく仏間 全体をCHOSHOM と呼んでいたが、他の住居では内陣を特に CHOSHOM TSHAMKO/TSHAMKONG/TSHAMKO と呼んでいた。

これらの部屋は、機能に対応した部屋名呼称が付けられるため、 設置場所や住居によって異なることはなく、他言語との対応が比較 的容易である。ただし、英語表記で storage となる部屋については、 ゾンカ語ではその部屋に保管する物によって呼び方が異なるため、 使われ方を把握した上で対応した部屋名呼称を選定する必要がある。 逆にいえば食品は PHUNG、米は MITHU、飼料はSATAO といっ たように貯蔵する食品、農作物や飼料等によって貯蔵場所の部屋名 呼称が異なることこそが、伝統的農村の暮らしとそこにおける価值 体系を映すものともとらえられ、ゾンカ語およびブータン伝統住居 に特徵的な点であるといえよう。

(2) 空間としての部屋名呼称

$\mathrm{BAKO} / \mathrm{BAKONA} / \mathrm{BACO} / \mathrm{BACONG}$ (中間の間、つなぎの空間)、 YOUCHU/YUCHU (側方への張り出し部)、JABYOUG (裏の空間)、 といったように、機能ではなく空間としての名で呼ばれている空間 がある。YOUTAKHA/YETAKA/YOTO (最上層、屋根裏) や BACHI/ BAKHE (中間層) などの階層の名称も類似のものととらえられる。 YOUTAKHA/YETAKA/YOTO に関し、No.6では階が異なるもの 
の、この直下階にあり、YOTO と階段で繋がっている部屋を、同一 の空間として認識しており、同じくYOTO と呼んでいる。

YOUCHU の用途は倉庫や子供部屋など、各住居によって異なる ほか、同じ住居であっても使われ方が変更されやすい。

次に、「部屋と部屋の間の空間」を意味する BAKO/BAKONA/ BACO/BACONG の使われ方はNo.2、No.23 では寝室、No.3 では 居間などとなっており、YOUCHU と同様に各住居によって異なる。

同様に、「中間層（主要な居住空間が 3 層目にある住居では 1 層 目と 3 層目の間の層)」は BACHI/BAKHE と呼ばれている。この層 にある部屋は必ずしも特定の部屋名呼称がつけられるとは限らず、 単に BACHI/BAKHEと呼ばれる場合がある。

最後に、No.2、No.6、No.7、No.22 にある JABYOUG はバック ルームにあたる空間であり、YOUKHA や CHOSHOM を表の空間 と捉えた場合の裏の空間である。ここに位置する部屋に機能に基づ く部屋名呼称があっても住民はこの空間を JABYOUG として認識 しており、通訳がゾンカ語で空間ではなく機能による特定の部屋名 呼称があるか質問して初めて各部屋名呼称を答える場合もあった。

(3) その他

特定の部屋名呼称が無い場合、過去の使われ方に基づく名で呼ば れる場合、本来用途以外の使われ方が付加されている場合があった。

特定の部屋名呼称が無かったものは No.6 と No.7 である。No.6 では増築部分の部屋に、No.7では過去に炊事場として使っていたも のの現在は特定目的で使われていない部屋と JABYOUG に位置す る部屋に、部屋名呼称がなかった。

過去の使われ方に基づく部屋名呼称は No.3、No.20、No.21 にあ る。No.3 及び No.20 は過去に牛部屋として使用していたが、現在 は別棟に牛部屋を移築したことで倉庫として利用している部屋を今 でも OKA（牛部屋）と呼んでいる。同様に、No.20、No.21 では、 過去に炊事場として使われていたが後に炊事場を別に設けたことで 現在は家族が座るなどの集まる場として使われている部屋を今も TAPTSON（炊事場）と呼んでいる。

\section{4-3. 屋内構成と呼称の特徵}

対象とした 7 住居を横断的に調査した結果、得られた各層の空間 構成及び部屋名呼称の特徴は以下の通りである。

1）伝統住居は層によって空間構成が異なり、1 層目は家畜部屋又 は倉庫・貯蔵などに用いられる非居住空間、その上層に主たる 居住空間があり、最上層は収穫物等の乾燥・保存場所である。

2) YOUKHA（居間、客間、寝室などの多用途で使われる生活の 中心空間）及び CHOSHOM（二間続きの仏間）とその内陣 TSHAMKO は必ず主たる居住空間に設置され、そこに至るつ

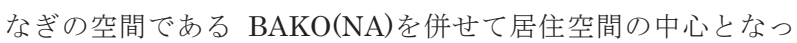
ている。伝統住居はこの中心部空間と、それ以外の YOUCHU などからなる縁辺部空間で構成されている。

3）部屋名呼称は機能、空間、設置場所等で決まる。そのため他言 語で室名を記録した場合、結果的に部屋の使われ方や、部屋や 空間のもつ性質が分かりにくくなる場合がある。

4）同じ使われ方であっても家によって部屋名呼称が異なる場合 がある。また、空間としての部屋名呼称 (YOUCHU、JABYOUG など）の場合は特に家によって使われ方が異なることが多い。
この為、伝統住居では部屋名呼称と併せ、使われ方や空間とし ての本来の性質や位置づけを確認することが重要と考えられる。

\section{5. 本稿のまとめ}

チュバ及びアツォ集落の伝統住居を対象に実施した 2 回の実測・ 実踏とヒアリング調查を通し、屋内空間の基本構成と各部屋の現地 ゾンカ語呼称および各部屋の使われ方を把握し、伝統住居の特徵に 関する以下の知見を得た。

1）伝統住居は層によって空間構成が異なり、1 層目は家畜小屋又は 倉庫・貯蔵などの非居住空間、その上層に主たる居住空間があり、 最上層は収穫物等の乾燥・保存場所である。主たる居住空間があ る階層の空間構成は、YOUKHA（居間、客間、寝室など多用途で 汎用に使われる部屋)、CHOSHOM（外陣及び内陣 THAMKO か らなる二間続きの仏間)、BAKO(NA)（中間の間、つなぎの空間） から成る中心部空間と、その周囲にある縁辺部空間（YOUCHU など）である。そのうち YOUKHA は最も多様な活動が行われる 空間であり、伝統住居の生活における中心的な空間となっている。 一方、CHOSHOM は二間続きとなっており、手前に僧侶が座る 外陣、その奥に TSHAMKO（仏壇のある部屋・内陣）が設けられ ており、空間構成の上でも重要かつ神聖な空間となっている。

2）部屋名呼称は機能、空間、設置場所等で決まる。また、同じ使わ れ方であっても家によって名前が異なる場合や、空間としての部 屋名呼称の場合（YOUCHU、JABYOUG など）など家によって 使われ方が異なることがある。そのため他言語で室名を記録した 場合、部屋の使われ方や、その部屋や空間の本来の性質が分かり にくくなる場合がある。特に、階段室と YOUKHA の間にある BAKO/BAKONA の空間は、炊事場（カマド）を具えていること で kitchen と訳されやすいが、部屋というより通路的な空間認識 でとらえられておりブータン伝統住居に特徵的な空間として特筆 される。また、貯蔵場所は、食品、米、飼料など貯蔵するものに よって細かく部屋名呼称が分かれる点に特に注意が必要である。

3）空辺が上座であることから、ブータンにおける室内の空間構成を 把握するために空の位置は重要なものである。しかしながら生活 の中に西欧文化が導入されたことで、家具の設置による用途の固 定や部屋の個室化などがみられるようになり、空辺等の空間作法 も変化しつつある。本研究では伝統住居の使われ方や空間構成に ついて、伝統的な部分と近代化に伴う変化の一端を確認すること が出来た。

本稿はブータン西部の二集落内における伝統住居の調查を実施し、 屋内空間の構成とその使われ方についてブータンの伝統住居の特徵 を記録することができたと同時に、ブータンの近代化による急速な 変化の一端を併せて記録寸ることができたものと考える。

一方、同じ使われ方をする部屋の部屋名呼称が複数存在すること も本調査で確認できた。この理由として部族間の交流によりチュバ 集落及びアツォ集落外で使用していた呼び名を調查対象が使用して いた場合、ゾンカ語の発音をラテン文字表記した際の表記摇れの場 合等いくつかは判明したが、判明しきれなかったものもあり、さら なる調査が必要であり今後の課題とする。

なお、本稿では紙幅の関係上、平面空間構成にの夕論じており、 断面空間構成については次稿以降で論じるものとする。 


\section{謝辞}

現地調查全体に多大なるご尽力、ご協力、資料提供等をいただいた ブータン王国政府公共事業省 Meghraj Adhikari 氏、Ugyen M Tenzin 氏、Tashi Penjor 氏、古市徹雄先生、遠藤政樹先生、小泉 俊雄先生、また特に通訳協力をいただいた Deki Yangzom 氏、 Yangchen Lhamo 氏、さらに本研究の構想から現地調查まで各部に 大変貴重なご助言ご協力と温かい応援を下さいました栗田靖之先生、 元倉真琴先生、星泉先生、永村裕子氏、川崎英明先生、千葉工業大 学ブータン伝統住居実測調查団メンバーに心より感謝申し上げます。 なお、本研究の一部は科研費（25501004）を受けた。

\section{注}

注 1) ブータン政府統計局データ（http://www.nsb.gov.bt/main/main.php, accessed 2015.4.1）に基づくと、首都のあるティンプー県の人口は 2010 年以降毎年前年比約 $11 \%$ 増で増加している。

注 2）自動車免許取得者数は 2008 年の 47,409 から 2013 年 91,010 に増加した 他 (National Statistics Bureau, Royal Government of Bhutan: Statistical Yearbook of Bhutan 2014. ISBN 978-99936-28-24-8, 2014.10）、ブータン政府統計局デ ータ (http://www.nsb.gov.bt/main/main.php, accessed 2015.4.1）に基づくと、 テレビの世帯普及率は $55.3 \%$ になった。

注 3）法令上は 30 度以上の傾斜地では一切の建築行為が禁止されている。

注 4）筆者らが聴き取りを行った際に、ブータン王国政府公共事業省人間居 住局都市専門官は、ブータン伝統住居で育った者には他では培われない価 值観が備わると述べ、現在の政府職員のほとんどを占める地方部の伝統住 居で育った世代が今後引退し、都市部で育った次世代のブータン人が国の 将来についての判断を担う時代が来れば、現在の現役世代とは異なる判断 や舵取りを行なう可能性があることを大変懸念していると述べていた。 (2013 年 9 月 19 日)

注 5）親族や知人以外の外来者を泊める際、危害や盗難リスクに備えてはし ごを取り外しておき階下へ自由に行き来できないようにするのだとのヒア リング結果もあり、そのような防犯上の利点もあったようである。

注 6）「チュ」は「川」の意味。

注 7）ヒアリング結果に基づく。

注 8）建物の実測と地形の測量の成果については参考文献 15)にまとめられて おり、このうちチュバ集落 8 住居の平面図・立面図・断面図については pp.58-153 に掲載されている。

注 9) 2013 年は 8 住居を対象としたチュバ集落だが 2014 年調査では調査期間 の制約のため、詳細なヒアリング調查が可能であった 4 住居を対象とした。

注 10）ゾンカ語（各地の方言含む）の発音をラテン文字表記する際の表記法 （綴り方）はブータン国内で特に統一されていない。そのため、本調查にお いて部屋名呼称の発音をラテン文字表記でノートに記入してくれた 2 人の 通訳の間で表記摇れがみられた。例えば、同じ発音に対して YOUKHA と YUKA というように異なる表記となるケースが多々あった。本論文では通 訳者によるノート記入表記を極力忠実に記載しつつ、表記摇れ又その他の 原因で複数の表記がある場合には必要に応じ補注を加えることとする。

注 11）No.6に対しては 2013 年調查でブータン国立博物館学芸員を通訳とし て初回調查を、2014 年はブータン政府公共事業省建築系職員を通訳として 再度詳細調查を行っているが、通訳 2 名の間で発音のラテン文字表記に違 いがあり、1 人目の通訳は THAPTSHONA, 2 人目の通訳は TAPTSON と 表記した。なお調査全体を通じ、実際にはBAKONA と呼んでいても調查 者に「この部屋は何か?」「室名は?」と問われると kitchen=THAPTSHONA であると答える傾向があり、調査には後出注 16 にも示寸難しさがあった。 注 12）この部屋はパロ地方で一般に YOUKHA（1 人目の通訳者による表記。 2 人目はYUKA と表記。いずれも「ユカ」と聞こえる同じ発音）と呼ばれ る部屋であるが、この家ではパロ地方に隣接する八（Ha）地方の方言で YOUKHA を指寸呼称「YUKI」で呼ばれていた。婚姻などによる交流はし ばしばみられ、それにより隣県の方言での呼称が伝わったものと思われる。

注 13） 2 つの表記は通訳者間の表記摇れであり発音は同じ「ユチュ」である。

注 14）最上層の呼称としてパロで一般的なのは YOUTAKHA（1 人目の通訳 者の表記。2 人目の通訳者はYUTAKA と表記。いずれも「ユタカ」と聞こ える同じ発音）という呼称であるが、この家では YOUTAKHA の短縮形で ある「YOTO」で呼んでいた。

注 15）息子夫婦以外の家族は現在も YUKI で就寝する。

注 16）BAKONA は家により単に BAKO と呼ばれる場合も多い。NA は屋内 (の空間や部屋）を意味する接尾語であり、他の様々な部屋名呼称の語尾に もつけられる。しかし今回調査では厳密にはNAがどのような空間認識の
もとにつけられるかまでは把握しきれなかった。なお、BAKONA が部屋名 としては英語に対応寸る語がなく、また THAPSHONA を含み、かつ大きな 四角い部屋であるため、部屋であるという認識があると思い込んで英語で この部屋は何という部屋かと質問してヒアリングすると kitchen との答え が返ってきがちであるが、この部屋全体を台所と呼ぶには広すぎるのは明 らかであり、がらんどうの部屋の片隅に炊事場がついた格好になっている。 注 17）ブータン政府公共事業省人間居住局都市専門官にブータンの一般的な 伝統住居の向きを聞いたところ、理想的・宗教的には東向きがよいが、通 常は、僧侣の住居などの特別な場合を除き、伝統住居は地形に沿って建て られ、その向きは土地の低い方が正面となる場合、次に川を向いて建てら れる場合があるとのことであった。また、道がある場合にそれに沿う場合 もあるとのことであった。

注 18）「NA」は屋内（の空間や部屋）を意味する。前出注 16 参照。 注 19）この伝統住居は 2011 年シッキム地震による建物被害があったため、 調査時点でもこの部屋を含む 3 階の一部が使用できない状態であった。

\section{参考文献}

1）花崎幂平：身体、人称世界、間身体性一親密圈の基礎を問う，斎藤純一編 「親密圈のポリティクス」ナカニシヤ出版所収, 2003

2) 杉浦 直: 東北地方における農村家屋母屋間取り形態の地域的差異と特色, -1^, アルテスリベラレス No. 32, pp.1-28, 1983.07

3）千森督子, 山本新平, 増田带紀 et al. : 紀南の民家の地方性と近代化過程 に関寸る生活史的研究, 熊野型民家の平面構成の特性と变遷, 住宅総合研究 財団研究論文集, No. 35 , pp.179-190, 2008

4）木多道宏, 土田讶恵子, 横溝愛 et al.: イスタンブル低所得者居住地区にお ける生活環境の持続のしくみに関する研究, その 2 , 住居の間取りの類型と 街路空間との関係性, 日本建築学会大会学術講演梗概集, 建築計画, pp.1313-1314, 2013.08

5）海日汗：モンゴル族住居の空間構成概念に関する研究：内モンゴル東北地 域モンゴル族土造家屋を事例として, 日本建築学会計画系論文集, No. 579, pp.179-186, 2004.05

6）中島伸, 久世啓司, 鈴木 敬雄, 前田昌弘: 歴史的建造物の現状と調查プロ グラムの概要, ブータンの歴史的建造物に関する調查報告, その 1 , 日本建 築学会大会学術講演梗概集, 建築歴史・意匠, pp.439-440, 2005.07

7）野間晴雄：ゾン (Dzong) 考,ブータンにおける城塞の立地・形態・機能, 研 究年報（奈良女子大学文学部）, Vol. 40, pp.73-101, 1996.03

8) ブータン王国建設省, 千葉工業大学建築都市環境学科ブータン伝統住居実 測調查団, 古市徹雄 et al. : ブータン伝統住居, ADP, 2010, pp.209-210

9）岸本章, 多摩美術大学ブータン調査グループ: 旅の写真帖から, ブータン の民家, -1-, パロ谷の農家, 住宅建築, No. 271, pp.152-155, 1997.10 10）岸本章, 多摩美術大学ブータン調査グループ: 旅の写真帖から, ブータ ンの民家, -4-, パロの古民家, 住宅建築, No. 274, pp.176-179, 1998.01 11）青木孝義, 冨永善啓, 江面嗣人 et al. : ブータン王国における民家等の 伝統的建造物保存修復に関する研究, その 1 常時微動測定結果, 日本建築 学会大会学術講演梗概集, 建築歴史・意匠, pp.495-496, 2012.09 12）江面嗣人, 友田正彦，青木孝義 et al. ：ブータン王国における民家等の 伝統的建造物保存修復に関する研究, その 3 版築の工法について, 日本建 築学会大会学術講演梗概集, 建築歴史・意匠, pp.563-564, 2013.08 13) ブータン王国建設省, 千葉工業大学建築都市環境学科ブータン伝統住居 実測調查団: ブータン伝統住居, ADP, 2010, pp.174-204

14）阿久井喜孝：ブータン王国の伝統的民家と集落に関する調查研究, 東京 電機大学総合研究年報, No.15, pp.27-38, 1996.5

15）ブータン王国建設省, 千葉工業大学建築都市環境学科ブータン伝統住居 実測調查団：ブータン伝統住居 IV, 西部チュバ・ニャンメイ編, 2015.08 16）金子将大，中島崇宏，川崎英明 et al. : ブータン王国西部地方における 伝統的集落調查, その 4 土地利用現況図の作成, 日本建築学会大会学術講演 梗概集，農村計画, pp.139-140, 2015.09

17）ブータン政府観光局, http://www.travel-to-bhutan.jp/, 2015.12.20 閲覽 18）宮下史明, GNH（国民総幸福量）の概念とブータン王国の将来：GNP か ら GNH $\frown$, 早稲田商学, No. $420 ・ 421$ 合併号, pp.39-74, 2009.09, p.53 19) 独立行政法人国際協力機構, ブータン王国貧困プロファイル調查（アジ ア）最終報告書, 2010.8, p.7

20）阿久井喜孝：ブータン王国の伝統的民家と集落に関する調査研究, 東京 電機大学総合研究年報, No.15, pp.27-38, 1996.5 


\title{
A STUDY ON THE SPATIAL ORGANIZATION OF FLOOR PLANS OF TRADITIONAL BHUTANESE HOUSES IN TWO VILLAGES CHUBA AND ATSUO, PARO DZONGKHAG, KINGDOM OF BHUTAN
}

Focusing on the name of each room/space in local Dzongkha language and room use

\author{
Aya ISONO* , Akiko YOSHIMURA** and Shota KANEKO*** \\ * Narashino Municipal Office, Dr.Eng. \\ ** Assoc. Prof., Chiba Institute of Technology, Dr.Eng. \\ *** Graduate School, Chiba Institute of Technology, B.Eng.
}

The original lifestyles in traditional Bhutanese houses are at risk of disappearance due to ongoing rapid modernization. This study aims to understand the spatial organization inside traditional Bhutanese houses through an empirical survey in Paro, Western Bhutan, on the uses of rooms and their names in local Dzongkha language.

The research objects were seven traditional houses located in two communities, Chuba and Atsuo, located about seven kilometers north of the urban area of Paro, which is the second-largest city in the western part of the Kingdom of Bhutan.

An on-site survey was carried out in the two villages to record the local Dzongkha name and the use of each room. In addition, the basic patterns of spatial organization and the use of each room/space were clarified and classified, and the following information on the characteristics of traditional houses in Atsuo and Chuba was ascertained.

1) The spatial arrangement of the traditional houses is different on each floor. The first floor is a non-residential space, which used to function as a barn for livestock and is now used for purposes such as storage. The living space is above this floor, and the top floor is a drying and storage space for the harvest.

2) The basic spatial organization of the main floor is, in order from the entrance, an intermediate space (Bako in Dzongkha), a living room (Youkha), and the Buddhist family chapel (Choshom) with an inner altar room (Tshamko). The main floor of three-story buildings is on the second level and that of four-story buildings is on the third level.

3) Common among the houses is the fact that the living room (Youkha) sees the most diversity in use and is regarded as the central space of life activities, while the Buddhist family chapel (Choshom) is the spiritual center of the house. The window side in the living room (Youkha) is the primary place for the view, sun and wind, and traditionally had precedence. The layout of the Buddhist family chapel, in which two rooms are joined together with the outer sanctum placed at the room entrance side and the inner sanctum placed at the far end, indicates its significance and high sanctity.

4) The ways of recognizing spaces find their expressions in local Dzongkha names, which differ from room names in English, thus reflecting the difference between cultures. Some names in Dzongkha (e.g., Bako, Youchu and Jabyong) express the placement of the space in the overall spatial organization rather than the room functions, as is the case in English. Also, Dzongkha room names for storage areas differ according to what is stored (e.g., Phung for food storage, Mithu for rice storage and Satao for fodder storage). These spaces/rooms do not have exact English translations, and it would be irrelevant to apply existing English room names to them. This should be noted for understanding the spatial organization, actual use and original characteristics of each room/space in traditional Bhutanese houses, which fostered Bhutanese people for a long time and engrave wisdoms on how to and what is to live in harmony with the environment. 